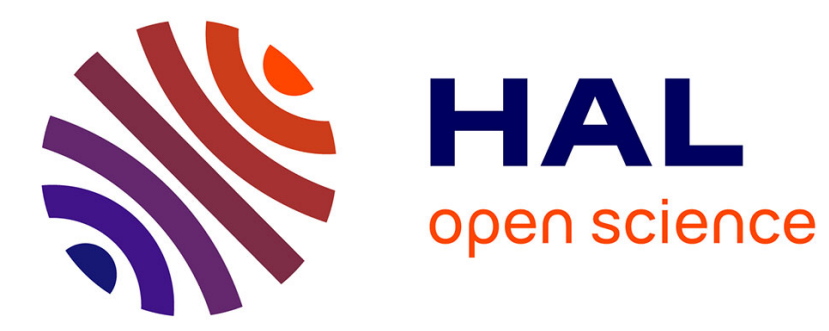

\title{
The systeme agraire concept in francophone peasant studies \\ Hubert Cochet
}

\section{To cite this version:}

Hubert Cochet. The systeme agraire concept in francophone peasant studies. Geoforum, 2012, 43 (1), p.128-136. 10.1016/j.geoforum.2011.04.002 . halshs-01374272

\section{HAL Id: halshs-01374272 \\ https://shs.hal.science/halshs-01374272}

Submitted on 13 May 2020

HAL is a multi-disciplinary open access archive for the deposit and dissemination of scientific research documents, whether they are published or not. The documents may come from teaching and research institutions in France or abroad, or from public or private research centers.
L'archive ouverte pluridisciplinaire HAL, est destinée au dépôt et à la diffusion de documents scientifiques de niveau recherche, publiés ou non, émanant des établissements d'enseignement et de recherche français ou étrangers, des laboratoires publics ou privés. 


\title{
The systeme agraire concept in francophone peasant studies
}

\author{
Hubert Cochet
}

\section{Abstract}

Among the many concepts used in farming systems research, the agrarian system—système agraire - stands out in the works of francophone agronomists, agricultural economists and geographers. It is an all-encompassing concept, capable of making sense of agricultural activities at a regional scale in a way that accounts for both ecological and socio-economic dimensions. The objective of this article is to trace the evolution of this original concept, reflect on the difficulties inherent to its use, and examine its relevance to agricultural research. After exploring its origins and development within the French school of Comparative Agriculture, the author analyzes its components in terms of constituting sub-systems. Next, the challenges associated with the agrarian system approach are addressed, particularly in terms of boundaries and scales of analysis. Part four discusses the similarities and differences between this approach and others, more commonly used by non-francophones. The article concludes with a discussion of the usefulness of the approach in terms of identifying obstacles to agricultural development.

Key words: agrarian system, farming system, peasant studies, comparative agriculture

\section{INTRODUCTION}

Among the spate of farming systems research conducted in the 1970-80s by agronomists and agricultural economists, French researchers authored a number of regional studies using what 
they called an "agrarian system" approach. During this period, enthusiasm for the agrarian system concept burgeoned, particularly in France, as holistic approaches to understanding agricultural transformations in Europe and developing countries gained in popularity. Researchers sought to understand the biophysical and socio-economic environment of farms using an all-encompassing approach that could illustrate the reciprocal interactions among the different elements in this environment, and between the environment and the farm itself (Deffontaines, 1991).

The agrarian system concept engendered a good deal of interest, giving rise to "agrarian system" departments in French public agricultural research institutions. ${ }^{1}$ Several agricultural geographers and agricultural economists formulated their own definitions, but it was under Marcel Mazoyer, successor to René Dumont and Chair of Comparative Agriculture at the National Agronomy Institute of Paris-Grignon, that the concept flourished.

In the following pages, I will reflect on the concept's originality and use in francophone research, especially in Comparative Agriculture, to understand archaic and contemporary agriculture worldwide. My objective is to highlight the wealth and complexity of this concept, as well its constraints. I will examine why the agrarian system concept is so little used in anglophone research and underscore the similarities that nevertheless exist between the French school of Comparative Agriculture and other approaches used by non francophones.

This paper begins with a review of the concept's origins in francophone research and shows how it evolved over time thanks to contributions of geographers and agricultural economists. Next, I analyze its components in terms of constituting sub-systems, namely the farming

1 INRA (Institut National de Recherche Agronomique), CIRAD (Centre International de Recherche Agronomique pour le Développement) 
system and the cropping system. Part three discusses the challenges associated with using the agrarian system approach. I emphasize the problem of boundaries and scale, and the importance of combining different levels of analysis. I point out the difficulties associated with applying the approach but also its great ability to analyze fast-changing agricultural transformations worldwide. Part four compares and contrasts the agrarian system approach used in the French school of Comparative Agriculture with approaches used by non francophones. The article concludes with a discussion of the usefulness of the approach in terms of identifying current obstacles to agricultural development.

\section{THE AGRARIAN SYSTEM CONCEPT: GENESIS AND DEVELOPMENT}

\subsection{Agrarian STRUCTURES or agrarian SYSTEMS? The contribution of FRENCH GEOGRAPHERS}

French geographers coined the term "agrarian systems," with André Cholley (1946) probably providing the first definition. Shortly after World War II, at a time when agriculture in Western Europe was on the cusp of major transformation, Cholley writes the following, with reference to research methods in rural geography: "We would be much closer to reality were we to consider agricultural activity in terms of a genuine combination or complex of elements from distinct areas, albeit closely related; these elements are so interdependent that it is inconceivable to radically change one without considerably affected the others, and thus 
modifying the whole combination in terms of its structure, dynamism, even external appearance" (Cholley, 1946).

Twenty years later, Paul Pélissier offers a remarkable example of a holistic and systemic approach to agrarian societies in his doctoral thesis on Senegalese peasants, although the agrarian system concept is not mentioned (Pélissier, 1966). The article, published in 1964 by Pélissier (with Gilles Sautter, Sautter and Pélissier 1964), "Pour un atlas des terroirs africains: structure-type d'une étude de terroir" ("Towards an atlas of African terroirs: template for a terroir case study"), was the first in an exceptional series of studies of African terroirs conducted by different researchers at the French Overseas Scientific and Technical Research Office (ORSTOM) under the supervision of the two authors. The "terroir school" contributed to knowledge of peasant agriculture, nature-society relations in rural areas, and analysis of agrarian systems, especially their productive efficiency (Bassett, Blanc-Pamard, and Boutrais, 2007). The concept of terroir designates the portion of land appropriated, managed and used by the group that resides on it and draws from it their means of existence (Sautter and Pélissier, op cit).

Thirty years after Cholley's article, Georges Bertrand revives not the "agrarian system" concept, but that of "agrosystem" in his book Histoire de la France Rurale. "Each agrosystem reflects a specific relationship between a type of rural society and a type of environment, in the material sense as well as in terms of behaviors and mentalities. Going from one agrosystem "model" to another corresponds to a shift in the relationship between the rural society and its ecological context. Analysis of these shifts is essential. It raises, from an ecological standpoint, the controversial issue of "agricultural revolutions" (Bertrand, 1975). 
In the wake of Histoire de la France Rurale, Claude and Georges Bertrand even advocate the study of landscapes as systems. "The complexity of landscape is morphological (form), constitutional (structure) and functional; one must not seek to diminish it by dividing it up... landscape is a system" (Bertrand and Bertrand, 1978).

More recently, another geographer, Jean Renard, wrote, "Agrarian landscape is also, in a vast space...the arrangement of the same repetitive elements that make up an agrarian structure; the result is an agrarian amalgamation that is, in fact, agrarian morphology... There is clearly the notion of a model or agrarian type [underlying this perspective], i.e. the recognition that beyond the diversity and complexity of shapes, there exists regularity, order, organization. This is proof that agrarian landscape, which is the arrangement of places, is first and foremost a social act" (Renard, 2002). Just about everything is there...except the term "agrarian system" itself.

Despite Cholley's remarkable openness, most rural geographers have used the term "agrarian system" restrictively. Therefore, for example, Roger Brunet, in his work Les mots de la Géographie, Dictionnaire critique (Brunet, 1993), defined agrarian system as follows: "Traditional category in geography, from an era when the term 'system' had little significance; mainly used to qualify the formal description of spatial organization in agriculture: the relationship between boundaries, land division and distribution, and occasionally elements of the agrarian regime." The term even seems to have disappeared from some recent dictionaries. Published in 2003, the Dictionnaire de la géographie et de l'espace des sociétés does not mention the term système agraire, although the English term, "agrarian system" does appear as possible translation for the French term structure agraire. (Levy and 
Lussault, 2003). The English term "agrarian system" is not mentioned in The Dictionary of Human Geography, regularly republished by R. J. Johnston and Company (2000).

The definition proposed by Brunet and a review of the aforementioned dictionaries show how the agrarian system concept has often been reduced to the notion of structure agraire. The latter term has been around much longer, and is used to refer to, on the one hand, the shape and disposition of plots, grasslands, pasture and forests and, on the other hand, the size of production units and different modes of exploitation (the "agrarian regime" in English): ownership, tenant farming, sharecropping, etc. By limiting the "system" to the "structure," there is less emphasis on the dynamic, evolving nature of agrarian societies and systemic interaction suggested by André Cholley or, before him, Claude and Georges Bertrand.

\subsection{The "agrarian system" of AGRICULTURAL ECONOMISTS}

Although it was initially introduced by geographers, the agrarian system approach was developed by French-speaking agronomists and agricultural economists during the 1970-80's, within the framework of Farming Systems Research (FSR) approaches promoted by the Association for Farming Systems Research and Extension. By the early 1990's, numerous works had been published. ${ }^{2}$ In French research, the approach was used in very different geographic areas, from the mountainous Vosges region of eastern France to Nepal (INRA, 1977, 1986). The INRA publication of Laurence de Bonneval's Systèmes agraires, systèmes

\footnotetext{
${ }^{2}$ See, for example, works by J. Brossier, L. de Bonneval, E. Landais (1993) and M. Sébillotte (1996), just to cite those coordinated by French agronomic research institutions.
} 
de production, Vocabulaire franco-anglais, (de Bonneval, 1993) testified to growing interest in the approach.

As de Bonneval points out, no one approach dominated the research carried out under the FSR label (de Bonneval, 1993). ${ }^{3}$ Nonetheless, most studies made the farm the focal point of a systemic analysis, rather than analyzing macro-level or all-encompassing systems that included the farm. Although studies were carried out on a regional scale, they were limited to a technical-financial viability analysis of the farm. This is why the agrarian system approach remained relatively distinct from those developed under the FSR framework. Because they generally did not take into account the "farming environment" as a system unto itself, the FSR approaches rarely addressed historical dynamics or changes to social networks (Dufumier, 2007). And yet, FSR studies were often used to inform development projects, especially analyses using Rapid Rural Appraisal methodology, which calls for the delineation of recommendation domains (Khon Kaen University, 1987; Colin and Crawford, 2000).

In French-speaking agricultural research, the social, economic and political aspects were taken into account by using a research and development approach, in which technical change and socio-economic change were considered inseparable (Jouve, 2000) It was precisely the drive to understand the interaction of evolving agricultural techniques on the one hand and economic and social systems on the other that pushed francophone agronomists to conceptualize the "agrarian system."

Raphael Larrère defined an agrarian system as "an organized set of relationships historically established between a specific social structure and the land being exploited." Influenced by

\footnotetext{
${ }^{3}$ For a comparative analysis of the emergence and development of the two families of approaches (FSR and systems research), see L. Fresco (1984) and D. Pillot (1987).
} 
the Marxist movement that characterized the early 1970s, Larrère insists on the historical nature of the concept. He espouses the underlying principle that "ever since men have organized themselves socially, they have maintained relationships with nature that depend on the social organization of production" (Larrère, 1974). He continues, "it is not the 'peasants' (a group of individuals who are different and isolated from one another) who exploit the land, nor the 'farmers of the future' (a sub-group of peasants who are better-equipped than the others), but a social formation composed of different categories of peasants, including artisans and service providers, among whom a social division of labor emerges. It is a society with its own laws and contradictions, and can also be a stage for conflict between the various constituting elements" (idem). Contemplated here within the framework of "social formation," the agrarian system concept takes on its broadest dimension.

The concept was redefined by Marcel Mazoyer as "a way of exploiting an agro-ecosystem that is historically defined and sustainable, adapted to the bioclimatic conditions of a given area, and responding to the social needs and conditions of the moment" (Mazoyer, 1987). It is a holistic concept that takes into account historical developments and the geographic traces of different forms of agriculture, and enables one to characterize major changes affecting production processes. According to Mazoyer, an agrarian system encompasses the agroecosystem and its transformations over time; production tools, labor force, and resulting artificialization (i.e., anthropogenic impacts on the land); the social division of labor among farmers, artisans and industrial actors, and the subsequent agricultural surplus and its redistribution; exchange and trade relationships, ownership relationships and power relationships; and finally, the ensemble of ideas and institutions that ensure social reproduction (idem). 
In order to characterize the complexity of this concept, I would argue that the agrarian system encompasses first of all the mode of exploitation of a given environment. This mode of exploitation includes (1) the characteristics of one or several agro-ecosystems; (2) a modus operandi, which itself is characterized by the farmers' technical heritage (tools, knowledge, practices, know-how that have evolved over time); (3) the way the environment has been transformed by man over time; (4) the resulting landscape; (5) the relationships between the different agro-ecosystems that make up the environment; and (6) soil fertility renewal mechanisms. The agrarian system also includes the social relations of production and trade that have led to its implementation and development (particularly the conditions influencing access to resources) as well as the conditions affecting the distribution of resulting value added. It includes a limited number of production systems, the mechanisms that differentiate these systems, and their respective trajectories. Finally, it includes the characteristics of the specialization and social division of labor, within each sector, and the economic, social and political conditions-particularly relative pricing systems - that influence the farmers' integration in global markets.

The concept of a system implies balance and reproducibility—sustainability, in today's terms. As such, the notion of fertility and how it is managed and restored is central, whether it is addressed at the level of the cropping system (discussed below), the farming system (discussed below) or the agrarian system. Much more than just a "natural" characteristic, fertility is as much the result of socio-economic processes and history as of "agronomic" evolution stricto sensu (Reboul, 1977, Cochet, 2004). For this reason, reflecting on how to renew fertility, and more generally speaking, on changes to biomass levels, is necessary to any agrarian system analysis. 
As a general rule, any mechanism that sustains and propagates the conditions enabling the exploitation of an agro-ecosystem is part of the agrarian system concept. This includes fertility management, reproduction of material and human resources, and the extent dominant social relationships are stable-in short everything that contributes to what could be considered a mode of regulation. "It is the interconnectedness and propagation of the different elements of the system that unify the agrarian system concept. Thus, although analysis of relationships between different levels of the system is important...[it] is not enough to predicate the notion of system. The rationale underlying the system's propagation must be identified in order to characterize its unifying elements and boundaries" (Kroll, 1992). Still, this interconnectedness does not preclude internal contradictions, differentiation or conflict. On the contrary, accumulation regimes and differentiation mechanisms, especially in farming systems, are what characterize the system itself; differentiation makes the system. In the words of Georges Balandier in his reference to social systems, "what matters is that a system defined in abstract, unadulterated terms presupposes a 'dynamism' precisely due to the differences that constitute it" (Balandier, 1971).

\section{SUB-SYSTEMS}

The agrarian system approach also requires the use of concepts whose efficiency and relevance are measured at more restrictive scales, namely the production unit and the cultivated plot or herd.

\subsection{The FARMING SYSTEM concept (or PRODUCTION SYSTEM)}


The farming system concept is generally relevant for farm holdings, i.e. the basic production unit, which is usually family-focused. This level of analysis is essential, as farms are the foundation of rural social fabric, where production processes are organized and production chains crisscross. Farm holdings are the elemental links that connect villages, giving rise to solidarities, contradictions, conflicts. Moreover, this level of analysis is particularly important, as it is where the field researcher makes first "contact," by interviewing farmers.

Rather than undertake a fastidious review of the different definitions of the francophone term système de production as it is applied to agriculture, or its Anglo-Saxon equivalent, farming systems (Fresco, 1984; Badouin,1987; Brossier, 1987; Pillot, 1987; Colin and Crawford, 2000), let us simply distill the essence of this concept.

The publication, in 1978, of the article "L'exploitation agricole vue comme un système" ("The farm viewed as a system") by Pierre-Louis Osty (1978) is a turning point in the French approach. It is followed by a succession of research using this new vision to better understand farmers" "practices" and "choices," and to adapt extension efforts. Similarly, the definition proposed the same year by CGIAR emphasizes the farmer as the main protaganist who "pilots" the farming system according to his choices and aspirations. (CGIAR 1978, in Fresco 1984; Colin and Crawford, 2000).

Although the concept can be applied to the individual enterprise level, to help understand how the family farm functions thus enabling the formulation of personalized advice, this "individualized" approach is insufficient for comprehending dynamics at a regional scale. This is why it is more efficient to apply the production system concept to a group of farms with the same resources (same amount of surface area, same level of mechanization, same 
size of labor force) in similar socio-economic contexts, with a similar crop mix-in sum, a group of farms that can be represented by the same model (Dufumier, 1995, Cochet and Devienne, 2006). In a typology of farm holdings based on this concept, each type of farm can be represented and corresponds to a model of one particular production system.

In their search for farming systems, economists and agricultural economists have run into problems trying to distinguish the identity and boundaries of the basic production unit in rural Sub-Saharian African societies, due to the embeddedness of the production process in the houshold unit, the accumulation unit and consumption unit. (Gastellu, 1979; Colin and Losch, 1994; Chia et al, 2006). The recent development of new institutional forms of agriculture in which labor and capital are increasingly disconnected poses a similar problem for the researcher trying to understand the production process. For example, where are the nerve centers and boundaries of different production units in an agricultural production enterprise that relies on a large number of small "owner-farmers" who are increasingly "ownerlaborers"?

Indeed, identifying the contours of a production unit, and thus the perimeters of the farming system concept is challenging, just as identifying the boundaries of an agrarian system whose elements are separated by great distances is no easy task. The study of the production process in and of itself, and by extension, the use of the farming system concept, thus has its limits. Still, even though the family unit and farm enterprise do not interlock seamlessly, and labor, land and capital often come from diverse origins, uniting these production factors and analyzing them as elements of a system that permits the production process to occur is useful, even if it is only in hypothetical terms. 


\subsection{FARMING SYSTEM versus ACTIVITY SYSTEM}

Particularly popular until the 1990s, the farming system concept was discarded by some agronomists and economists for the "activities system." In many contexts, family strategies encompass more than basic agricultural activities and can only be understood in light of a broader perspective. In short, the rationale underlying farming systems cannot be understood without reference to a "meta-system, called the activities system, that genuinely constitutes the sphere in which farmers' practices and choices appear coherent" (Paul et al, 1994). ${ }^{4}$

The pluriactivity of farmers is nothing new (Chayanov addressed it in his own way in 1924). In Western Europe, for example, in a not too distant past, farmers were also carpenters, wheelwrights, shoemakers, cheesemakers, butchers and shopkeepers. Moreover, family members who were not working on the farm all year (or all day) would commonly work as peddlers, chimney-sweepers, lumberjacks, etc. Pluriactivity was the rule (Mayaud, 1999). It is only in recent times, with specialization in basic, unprocessed food production and systematic use of inputs and tools produced off-farm that pluriactivity has decreased considerably. This dynamic can be observed in very different historical and geographical contexts. In many regions of Sub-Saharan Africa, for instance, where rural populations were pluriactive (fishing, hunting, gathering forest products, trading and long distance commerce of cola nut in addition to farming), even specialized laborers like blacksmiths were farmers, especially since village elders offered them land to encourage them to settle in the village. The colonial administration drastically reduced the populations' mobility as well as pluriactivity via a series of forced labor and settlement measures targeting native populations, thereby cutting off their access to certain areas and resources (Verdeaux, 1997).

\footnotetext{
${ }^{4}$ In anglophone circles, this concept is addressed in terms of "rural livelihoods"( Ellis, 2000).
} 
The residual pluriactivity resulting from these specialization processes was not studied; partly because those who were affected were not considered "real farmers", especially in France, and partly because anything "outside" the farming system strictly speaking, namely farmers' production and trade relationships, was rejected as part of the undifferentiated amalgam referred to as the "economic environment."

Now that pluriactivity is once again on the rise in many parts of the world, it seems important to distinguish different types of "pluriactivities:" those resulting from a de facto semiproletarianization of farmers and increasing vulnerability, those that help improve living standards and productive investments (Haggblade et al, 2005; Dufumier, 2006); and those that contribute to building or maintaining patrimony in view of retirement. In the first type, pluriactivity is the consequence of insufficient agricultural income; the extra revenue is needed to make ends meet. In other cases, pluriactivity is "structural;" the farming system is just one element. The farms may be small (sometimes limited to a garden or an orchard) and generate limited income, but they are not at risk of disappearing because they are elements of a larger activities system that involves international migration. Anything that is part of an "activities system" and that can help explain the why and how of a productive process in agriculture (especially one that continues to function even when conditions for profitability are no longer in place) must be carefully examined.

Even when agriculture is not the sole or primary activity of a rural household, agricultural activities are still organized as a system. Therefore, even subsistence farming can be analyzed using the farming system concept. In this respect, the farming system is a sub-system of an activities system - a smaller part of a bigger whole. 
Moreover, it is important to underscore that the use of the agrarian system concept is not limited to analysis of just the agricultural production process, strictly speaking. The growing specialization of farmers in primary production segments, the increasing importance of upstream and downstream sectors in supplying the means of production and processing, the growing distance between producers and consumers, urbanization, national and international migration have led some to call into question the usefulness of the agrarian system concept, as societies (even rural ones) are less focused on agricultural production strictly speaking (production of unprocessed or barely processed raw materials).

Nonetheless, this new division of labor throughout the food production chain, from producing raw materials to the consumer's plate, is part of an agrarian system. Indeed, this division of labor and the resulting commodity chains, are the building blocks of the agrarian systems that have emerged from the agricultural revolution. In other words, the agrarian system concept must not be limited to the sphere of unprocessed primary production.

\section{3. The CROPPING SYSTEM CONCEPT}

Analysis of cropping and animal husbandry practices also calls for a systemic approach. To study and understand cropping practices, agronomists refer to cropping systems. But here again, the term has many meanings! For years, geographers used it (and still use it) to define the typical crop of the agrarian system $x$ or $y$ that is characteristic of a given region. Some economists, less tuned into the technical aspects of agricultural production and the requirements for a farming system to operate, occasionally used the term cropping system to refer to the combination of all crops grown on a farm (a combination that does not always 
constitute a system at this level of analysis). This is also the way anglophones used the term (Zandstra, 1982).

In francophone research, agronomists defined the concept more precisely, turning it into an efficient tool for understanding what was happening in the field. Researchers demonstrated that what occurs at the plot level—what grows, how it grows, and under what conditions - as well as the history of that plot (the "preceding" effect ${ }^{5}$ ), functions as a system; or at the very least can be analyzed in terms of a system.

It is using this rationale that agronomist Pierre de Schlippé, in analyzing manual Zande agriculture (Congo) in the 1950s, established "field types," a term he defined as follows. "A field type is a structural concept: it refers to the combination of crops either planted in association when seeded simultaneously or successively, planted in succession during the same season, or planted in successive association. [Each field type] is based on a particular ecological environment and is characterized by specific cultivation practices that depend on specific moments in the agricultural calendar" (de Schlippé, 1956 : p.100). A surprisingly modern definition given the era.

As such, the cropping system concept is not applied to a crop, but to a plot (or group of plots) cultivated in a particular way. It encompasses the crop(s) that are cultivatedthe crop associations, crop successions, and the ensemble of techniques used according to a specific sequence and pedo-climatic conditions. The cropping system concept is considered a "sub-set of the farming system, defined by the crops, sequencing and planning (the logical and orderly combination of cultivation techniques)" (Sébillotte, 1976).

\footnotetext{
${ }^{5}$ Preceding effect: aggregate of effects of one crop on the next crop.
} 
At the same level, domestic herds can be analyzed using the concept of the livestock system. It integrates aspects regarding herd composition (genetic characteristics, demographic pyramid, sex ratio), feeding practices, forage calendar and herd management (herd movements, breeding, care). ${ }^{6}$ Intimately related, all of these elements can also be analyzed as a system; feeding practices often are the keystone of such an analysis.

Analysis of a cultivated area in terms of a cropping system or a herd in terms of a livestock system naturally entails integrating elements, like tools or labor, that are also elements of the farming system; nevertheless, cropping and livestock systems are still just sub-systems of the farming system. With the exception of the rare farming system comprised of one cropping or livestock system, it is the combination of different sub-systems that constitutes a system at the scale of the farm.

\section{CHALLENGES}

\subsection{BOUNDARIES and SCALE}

Applying the agrarian system concept is not always easy. There is the issue of boundaries, for example. How to define the limits of an agrarian system and geographical area where the concept will be most relevant? A village, a micro-region, an entire country? ${ }^{7}$

\footnotetext{
${ }^{6}$ For a review of the use of this concept in Europe, see A. Gibon et. al. (1999).

${ }^{7}$ The above-mentioned French-English dictionary by de Bonneval is testimony to the lack of clarity regarding this question (1993).
} 
If there exists a scale of analysis where relationships between basic production units impose a particular form of land use, where they are inscribed into the landscape to the point they can be "read" and where they constitute a historical, coherent, socially determined and sustainable system, it has to be the village or rural community. There are many examples of the agrarian system concept used at this scale, such as village agrosystems in West Africa (Jouve and Tallec, 1994) and terroir studies conducted under the supervision of geographers Gilles Sautter and Paul Pélissier. For French rural geographers of the "terroir school," agrarian systems are characterized by a spatial dimension. The terroir is not just a scale or framework of activities; it is a specific unit of socio-spatial organization (Bassett, Blanc-Pamard and Boutrais, op cit).

Other examples of research on agrarian systems at this scale of analysis can be found in work carried out in the Andean Cordillera on community organization of collective high-altitude cropping systems and land management (Morlon (ed), 1992). Even in Europe, many villages have been analyzed to better understand what agriculture looked like prior to the recent transformations of the last fifty years. Indeed, it is often at this scale that agrarian landscape best reflects the spatial expression—what one sees — of an agrarian system.

But, it is also possible for a great number of villages to leave the same mark on a landscape; a large swath of land may have similar characteristics and reflect common rules. In addition, what can be observed at the limits of a village depends on the elements situated outside those limits, and may not be entirely taken into account at the village scale. All villages or communities whose activities imprint the landscape similarly and are organized around the same rules and institutions would be considered part of same agrarian system. In other words, the geographic boundaries of the agrarian system would be determined by the territorial 
expansion of these shared rules and practices (Jouve, 1988). When this is case, "village" agrosystems represent an intermediary level necessary for understanding agrarian systems, a rung between the farming system and the regional agrarian system (Marchal, 2000).

The agrarian system concept can also be used to classify and characterize the agriculture of much larger geographical areas, as Marcel Mazoyer and Laurence Roudart suggest. They distinguish, for instance, forest agrarian systems, irrigated agrarian systems of the Nile Valley and agrarian systems characterized by fallow and light draft animal cultivation in temperate regions - always using the plural form "systems" to indicate that the category often refers to a family of agrarian systems (Mazoyer and Roudart, 2006). It is a concept that enables the classification of innumerous forms of agriculture identified throughout history and contemporary society into a limited number of systems, each characterized by a particular type of organization and functioning (idem).

Still, the issue of delineating the boundaries of agrarian systems remains. Must it absolutely be resolved? In fact, there is no rule against mixing and matching different levels and approaches to distinguish, on the one hand, a local agrarian system, or "elemental agrarian system," relevant for studying similar issues at a micro-regional level (Jouve, 1988, Deffontaines, 1991) from a broader agrarian system that groups together several local agrarian systems that are largely interdependent.

This approach is used by Marielle Pépin-Lehalleur and Gilles Sautter in their work on Mexico: "The idea of elemental agrarian systems fundamentally brings into play the association of a number of components that are not just juxtaposed but more or less interdependent. It implies (...) a certain degree of spatial consistency between functional 
units — villages or communities, agricultural enterprises or family farms - that participate in the same agrarian system." For these authors, a regional agrarian system is "a higher level of systemic interaction that overarches the different elemental agrarian systems that are more or less clearly defined" (Pépin-Lehalleur and Sautter, 1988). Another example from Mexico illustrates this notion. Two contrasting and neighboring agrarian systems were coexisting in the western mountains of the Michoacán. One was characterized by extensive cow-calf operations on temporary fenced-in prairies on slash-and-burn, and was based on relationships of private property and sharecropping. The other was a system of mixed cropping and animal husbandry practiced by Indian families on collectively managed community lands. The differences between the trajectories of these two agrarian systems could only be understood at the level of the pioneer front, where it was clear that the first system was advancing to the detriment of the second (Cochet, 1993).

\section{2. COMBINING SCALES of observation, analysis and understanding}

The agrarian system concept was first used by geographers and agro-geographers at a regional scale. The notion of farming system or production system was initially the domain of economists, agricultural economists and agronomists. The cropping system concept was developed by agronomists. It is the combination of these different scales of analysis and concepts, and the holistic approach of the agrarian system, which makes the French school of Comparative Agriculture original in its comprehensive approach to world agriculture.

The Comparative Agriculture approach makes it possible to zoom in and zoom out on different levels of analysis, and move frequently from one scale of analysis to another (Table 1): from the plot or herd where practices can be observed, to the production unit or farm 
enterprise, where different cropping and livestock systems are integrated, to the region or country level, where the agrarian system concept can be applied. These are not only three different and interconnected spatial scales, but three interdependent levels of functional organization. Countries, sub-continents and the world are also relevant levels of analysis, given competition facing farmers worldwide.

Table 1: Nested scales of analysis

\begin{tabular}{|c|c|c|c|}
\hline & \multicolumn{3}{|c|}{ Agrarian System } \\
\hline & \multicolumn{2}{|c|}{$\begin{array}{r}\text { Production System (farming } \\
\text { system)/Activity System }\end{array}$} & \\
\hline & $\begin{array}{c}\text { Cropping } \\
\text { System/Livestock } \\
\text { System } \\
\end{array}$ & & \\
\hline $\begin{array}{l}\text { Level of } \\
\text { analysis }\end{array}$ & Plot/herd or flock & $\begin{array}{c}\text { Farm/production } \\
\text { unit }\end{array}$ & Village/region/country \\
\hline $\begin{array}{l}\text { Type of } \\
\text { analysis }\end{array}$ & $\begin{array}{l}\text { Agronomic/Ecological } \\
\text { (bio-technological) }\end{array}$ & $\begin{array}{l}\text { Agro-socio- } \\
\text { economic }\end{array}$ & $\begin{array}{l}\text { Agro-geographic and } \\
\text { socio-economic }\end{array}$ \\
\hline
\end{tabular}

A systems approach to agrarian systems effectively rejects the notion that problems can be understood-let alone resolved - from one viewpoint only. "Agronomic" rationale (crop types, crop succession, planning and sequencing) must be examined in systemic terms at the plot level, i.e. at the scale of the cropping system. But to genuinely understand a farmer's choices and practices, the researcher much look at the level where cropping and livestock systems are combined, i.e. at the scale of the farming system. Similarly, while the livestock practices of domestic herds must be analyzed in terms of a livestock system, uncovering a farmer's rationale also requires analysis of the farming system (Cochet and Devienne, 2006). 
The coffee crisis in Burundi illustrates the importance of combining scales of analysis. During the early 1980s, average coffee yields in Burundi began to drop, causing experts to focus on fertility and pest problems affecting coffee crops. However, these experts limited their analysis to the cropping system, at the plot level, which led to a dead end. Indeed, the technical solutions that agronomists had long imposed on coffee farmers, which included mulching, appeared to be the solution to the crisis. From a cropping system perspective, mulching would lead to (i) decreased evaporation during the dry season, (2) increased fertility, (3) protection against soil erosion, and (4) efficient weed control. Yet in theory, farmers were already applying this "solution." So why were yields dropping?

In fact, understanding the crisis required analysis of the production system and social dynamics. By shifting scales of analysis from the cropping system to the production unit, and replacing a strictly agronomic approach with an socio-agro-economic one, it became clear peasants were not only struggling to amass the necessary biomass to mulch, but mulching came with high opportunities costs. Indeed, as the population grew and land became a rare resource, farmers increasingly felt the negative effects of transferring biomass to coffee plantations and away from food crops. Consequently, they were not mulching as expected (Cochet, 2001, 2004). Moreover, it became apparent that social dynamics between farmers, extension services, and government authorities were such that farmers had no other option to mulching, despite its negative impact on their activities.

In order to understand the coffee crisis, identify possible solutions and overcome the crisis, it was necessary to go beyond a purely technical one-dimensional (the cropping system) approach. 


\subsection{RAPID TRANSFORMATIONS and GLOBALIZATION}

Another challenge of the agrarian system approach emerges when different forms of agriculture become increasingly difficult to distinguish spatially, such as, for example, when a large part of the labor force migrates seasonally or even pluri-annually, over long distances, but continues to impact agriculture in their home communities by sending remittances. Illustrations of this phenomenon include migrants from the Senegal River valley settled in Parisian suburbs, Mexican peasants with generations of family members working intermittently (or settled permanently) in the United States, and Ecuadorian migrants laboring in Spanish irrigated agriculture. It is not uncommon for a large portion of a region's labor force to be absent for part of the year and yet more than half of household income comes from remittances. The issue of long distance migration raises the question of which boundaries to use to demarcate a particular type of agriculture under the agrarian system approach. Indeed, agrarian systems do not function in a vacuum; they are open systems. However, far from calling into question the approach's relevance, migration and the diminishing share of farm revenues often reveal a crisis within an agrarian system, and contribute to its restructuring under another form.

The unprecedented growth of long distance commercial trade (merely amplified by contemporary globalization) makes agrarian systems more open than ever. As a result, some of the conditions required for their reproduction can only be identified by searching far and beyond the region where the system is found. Jean-Christophe Kroll aptly describes this situation: "As soon as non-agricultural spheres of activities become dominant and the prevalent production and distribution relationships start to structure society, reproducing the conditions required for agricultural activity depends increasingly on factors outside the 
agrarian systems themselves...distant markets increasingly mediate the production and consumption of food stuffs, to the extent that there is no longer any immediate, visible compatibility between the evolution of production capacities of agrarian systems worldwide and food demands to be met." (Kroll, 1992).

Rapid changes to agriculture during the last fifty years have made it more difficult to use the agrarian system concept. It is easier to analyze a relatively "stable" situation and construct an agrarian system - i.e. formulate a systemic depiction that provides an overall understanding of agriculture - than to analyze a system that is so dynamic that the various elements and their reciprocating interactions just barely have time to stabilize before transforming again. Be it the rapid transformations to West European agriculture following World War II or the brutal competition now faced by farmers in developing countries, it is often easier to reconstitute an "archaic" agrarian system, deconstructing the elements that led to its decomposition and transformation, than to characterize current agrarian systems or those to come...Perhaps the agrarian system concept is easier to wield when applied to history, to lay the groundwork of a system, than to rapidly changing modern agriculture.

Similar difficulties appear when trying to understand and anticipate agrarian dynamics on pioneer fronts. A pioneer front does not have clearly distinguishable geographical boundaries (beyond which other, distinct agrarian systems can be found) and is difficult to analyze diachronically (i.e. identify the moment when one agrarian system transformed into another). The inhabitants, their technical skills and their practices advance with the pioneer front and evolve with the changing environmental, human, economic and social conditions. Therefore, the process of spatial expansion is not isomorphic since agricultural practices and social relations evolve behind the front, as a consequence of population growth, new development 
opportunities and migrations. Nor is it a strictly temporal process whereby different agrarian systems succeed each other in a given territory, since the development processes of a particular area are also largely determined by what is taking place behind and beyond the front.

Pioneer fronts have become increasingly common over the last fifty years; to study them, researchers must adapt their tools and concepts. It is the process, namely its spatial and temporal components, which must be analyzed and understood. For instance, it is impossible to understand the agrarian systems of the forested regions of Côte d'Ivoire without placing them within the larger framework of the cacao and coffee pioneer front that has swept the southern half of the country over the last fifty years. Each area and each time period must be understood as being part of a whole, part of a process; identifying this overarching process is ultimately what makes it possible to characterize the agrarian system in motion.

More generally speaking, the comparative study of agrarian systems using a synchronous approach must be paired with a diachronic approach that examines their succession and sequence over time. Making sense of how major changes mark the history of agrarian societies requires the agrarian system concept. Identifying crises and agrarian transformations is inherent to agrarian systems research. While the concept requires the researcher to "stop time" and examine the structure and functioning of an agrarian system at a given period in history (even though the dynamics of this period are the ultimate object of study), analysis of transition periods - the lapses in time during which transformations that will eventually give birth to a new system emerge-is dialectically related. Granted, transformations are difficult to identify without having at least a hypothetical notion of what things looked like before and after; nonetheless, understanding transformation is what permits the researcher to better 
understand the evolution of an agrarian society. At the same time, agrarian systems are not stable structures, nor are agrarian transformations necessary to transition from one system to another. Internal dynamics, sometimes combined with external factors, can provoke a major rupture and ultimately lead to a new agrarian system.

\section{SITUATED BETWEEN THE LIFE SCIENCES AND SOCIAL SCIENCES: THE DELICATE POSITION OF THE AGRARIAN SYSTEM CONCEPT}

The agrarian system concept is complex, and, admittedly, demanding. This complexity is due to the fact that the agrarian system approach requires the combination of very different scales of analysis and must include a description of the relationships that connect the technical sphere to the social sphere, or, in the words of Mazoyer and Roudart (2006), the cultivated ecosystem to the social productive system. The agrarian system cannot simply be considered a technical system that describes agricultural practices, nor reduced to structures agraires. The difficulty lies in analyzing both transformations in agricultural practices and changes to social relations, not just locally but globally. This is what distinguishes research using the agrarian system approach from farming system research in Anglo-Saxon countries (Dufumier, 2007).

The systems approaches developed by English-speaking colleagues under the FSR framework in the 1970-80s rarely integrated the historical dimension of agrarian systems nor did they examine the relationship between farmers' technical choices and the socio-political context. This is due to two reasons. First, the agrarian system approach evolved along side (and not in conjunction with) those labeled FSR. Second, the agrarian system concept simply did not gain popularity in the UK or US. 
It appears that in Anglo-Saxon academia, two schools of thought dominated agricultural and rural research. On the one hand, there were the approaches associated with FSR, based on the study of the technical processes from a systems perspective, particularly at the scale of the agricultural production unit (Colin and Crawford, op cit). Favored by agronomists and researchers from the agricultural sciences, these approaches studied systems and their modus operandi at time $t$ (today), in view of making technical recommendations. They gave little credence to long-term processes; historical elements; access to resources; distribution of value-added and its consequences; social relations; mechanisms that differentiate one production system from the next; or the factors that influence farmers' and rural populations' integration into global society.

On the other hand were the social approaches, pursued by social scientists less interested in the systemic nature of production processes than their agronomist counterparts. These approaches proliferated under the nomenclature peasant studies or agrarian studies (Bernstein and Byres, 2001). Research using these approaches made references to the agrarian political economy, sociology and history, and focused precisely on the aspects FSR studies underemphasized or ignored: social dynamics, history, economic and political context and the relations that connected farmers to society. They emphasized social differentiation within rural societies, social relations, and the role of market integration in the growing inequalities in rural societies in developing countries. In peasant studies, the system concept was rarely elicited because the technical process was rarely the focus of analysis. In fact, there was a certain distrust of the systems approach. In the eyes of these researchers, efforts to characterize a system-its "balance point," “internal coherence," "retroactions", "regulations", and "reproducibility"-were not compatible with the evidence of conflicts, 
tensions and internal differentiation. It was an approach that did not pay enough attention to the social dynamics of production and trade, the study of crises and transformative periods, and therefore history.

The proliferation of research in peasant studies, which appeared in English-speaking world in the 1980s gave rise to a new federating theme that accounted for physical and human factors in environmental degradation (Blaikies, 1985), from which would materialize the field of political ecology (Peet and Watts, 1996). Political ecology postulates the social and political origins of ecosystem degradation and questions the virtue of public environmental policies as well as the strategies and resistance that result from these policies. Political ecology makes it possible to revisit peasant practices that were condemned, and reassess them from a perspective that recognizes their unique rationale and coherence. Along the same lines, the more recent field of environmental history offers a framework to probe the historical dimension of peasant practices, highlighting the complexity and dynamics of nature/society relations, particularly between farmers and their ecosystems (the relationship between intensification and the environment (Tiffen and Mortimore, 1994 ; Fairhead and Leach, 1996).

The French school of Comparative Agriculture attempts to reconcile these two approaches and promote cross-fertilization through the agrarian system concept: a systemic approach to productive processes combined with a deep understanding of their relationship to social processes throughout time. Although the agrarian system is not at the center of the conceptual underpinnings of American political ecology, the latter has some similarities to the French school of Comparative Agriculture. It posits that agrarian dynamics are the result of the evolution of nature/society relations and their expression at the interface of bio-technical 
processes and socio-economic developments. The Yale University program in Agrarian Studies, created under the direction of James C. Scott in the 1990s, was established in reaction to the ahistorical nature of most research on the "development" and "modernization" of farmers and rural areas. It is based on two principles: (1) more extensive use of local knowledge and practices, by putting fieldwork at the center of analysis and (2) a comparative approach that is based on a multidisciplinary corpus of knowledge (Scott and Bhatt, eds, 2001).

The agrarian system concept is undoubtedly too complex and broad, or too difficult to implement within the framework of mono-disciplinary research project or extension project, for it to be widely used within an overly specialized scientific community that shies away from collaboration between the "hard" sciences and social sciences. Is its explicative vocation overrated? Is its use limited to that of a kaleidoscope - a perspective of one reality through a variety of filters?

The ebbing of the agrarian system approach forty years after its appearance in French public agricultural research institutions may lead one to believe the approach, with its regional scale of analysis (where it is most relevant), is dying out. However, the agrarian system concept and the analyses it engenders, has a rich future. Its disregard by some agronomists has left a void. Too often, anything beyond the farm is now addressed in terms of "economic environment" or the very narrow "value chain approach," when in fact the relationships between these "external" elements are complex and call for a systemic analysis. Moreover, given renewed interest in all that is "locale," "paysage," and "territoire" in environmental approaches as well as the growing need for holistic approaches to problem-solving and the embedded nature of all that is "technical" and "social", it is time to pay greater attention to this scale of analysis, to apprehend the whole, so as to understand its parts. 


\section{CONCLUSION}

In contemporary society, no problem can be addressed at a single scale of analysis and no solution can emerge from a single perception of reality. The interdependency of cropping systems and farming systems is also true of farming systems and agrarian systems. The agrarian systems of a given region are interdependent on those on the other side of the globe. Indeed today's world is characterized by the nestedness and interdependence of all forms of development... and under-development.

The French school of Comparative Agriculture aims to make sense of the many forms of contemporary agriculture worldwide and to draw overarching lessons that avoid broad generalizations or overly simplified modeling (Dufumier, 2006). In the last thirty years, this perspective has defined comparative agriculture studies in France, guiding conceptual and theoretical developments (Cochet et al, 2007, Dufumier, 2007). There are two major dimensions to this school of thought: (i) agricultural transformations and the crises of agrarian systems, and (ii) identification of the resources and conditions needed to anticipate or overcome these transformations and crises. By sifting through complex historical processes, comparative agriculture seeks out specificities and similarities, and aims to underscore linkages between the remnants of former agrarian systems and the elements of new ones. This involves identifying continuity and discontinuity. In sum, it entails reconstructing history to make sense of the agricultural development of a given society.

Thanks to the scientific concepts that have emerged out of the French School of Comparative Agriculture, namely the agrarian system, it is possible to understand agricultural 
developments throughout history, including those sometimes interpreted in terms of "crises" or "agricultural revolution." In conjunction with disciplines such as history, archeology, ethno-botany and history of technology, comparative agriculture sheds light on agriculture's evolution. ${ }^{8}$ But even beyond this fundamental contribution, historical research on agriculture brings a different perspective to contemporary contexts, which can help identify the obstacles and bottlenecks impeding present day agricultural development.

\section{Bibliography}

Badouin R., 1987. L'analyse économique du système productif en agriculture. in Cah. Sci. Hum. 23 (3-4), ORSTOM, Paris, 1987, pp. 357-375.

Balandier, G., 1971. Sens et puissance. Presses Universitaires de France, Paris.

Bassett T., Blanc-Pamard C., and Boutrais J. 2007. Constructing locality: the terroir approach in West Africa. Africa 77(1): 104-29.

Bernstein H., Byres T.J., 2001. From Peasant Studies to Agrarian Change. Journal of Agrarian Change, Vol. 1 $\mathrm{N}^{\circ}$. 1, January 2001, pp. 1-56.

Bertrand, G., 1975. Pour une histoire écologique de la France rurale. Histoire de la France rurale, vol. 1, edited by Georges Duby and Armand Wallon, Editions du Seuil, Paris, pp. 34-113.

Bertrand, G., Bertrand, C., 1978. Le paysage entre la nature et la société. Revue géographique des Pyrénées et du Sud-Ouest, April 1978, vol 49, fascicle 2, Presses Universitaires Le Mirail-Toulouse.

\footnotetext{
${ }^{8}$ See also D. Rindos' approach (1984) in the case of the neolithic spread of agriculture.
} 
Blaikie P., 1985. The Political Economy of Soil Erosion in Developing Countries. Pearson Education, Longman Scientific \& Technical, New York, NY, USA

Brossier, J., 1987. Système et système de production, note sur les concepts. in Cah. Sci. Hum. 23 (3-4), ORSTOM, Paris, pp. 377-390.

Brossier, J., de Bonneval, L., Landais, E. (eds), 1993. Systems studies in agriculture and rural development. INRA, Paris.

Brunet, R., 1993. Les mots de la Géographie, Dictionnaire critique. Published by Reclus, la Documentation française, Paris.

Chia, E., Dugué, P. and Sakho-Jimbira, S., 2006. Les exploitations agricoles sont-elles des institutions ?, Cahiers Agricultures vol. 15, n 6, novembre-décembre 2006, pp 498-505

Cholley, A., 1946. Problèmes de structure agraire et d'économie rurale. Annales de géographie, $\mathrm{N}^{\circ} 298, \mathrm{LV}$, April-June 1946, pp. 81-101.

Cochet, H., 1993. Des barbelés dans la Sierra, origines et transformations d'un système agraire au Mexique. ORSTOM Editions, collection “A travers Champs”, Paris.

1Cochet, H., 2001. Crises et révolutions agricoles au Burundi. INAPG/Karthala, Paris.

Cochet, H., 2004 Agrarian dynamics, population growth and resource management: the case of Burundi. GeoJournal, An International Journal on Human Geography and Environmental Sciences nº0:111-122 (2004), Kluwer Academic Publishers, The Netherlands.

Cochet, H., Devienne, S., 2006. Fonctionnement et performances économiques des systèmes de production agricole : une démarche à l'échelle régionale. Cahiers Agricultures vol. 15, n 6, novembre-décembre 
2006, p.578-583.

Cochet, H., Devienne, S. and Dufumier, M., 2007. L'Agriculture Comparée, une discipline de synthèse ? Economie Rurale 297-298/January-March 2007, pp. 99-112.

Colin, J.-Ph., Losch, B., 1994. But where on Earth has Mamadou hidden his production function? French Africanist Rural Economics and Institutionalism, in Anthropology and Institutional Economics, J. Acheson (ed.), University Press of America, Lanham, USA : 331-364.

Colin J.-Ph and Crawford E. W. (Eds.), 2000. Research on agricultural systems: accomplishments, perspectives and issues. Huntington, NY: Nova Science Publishers, Inc..

Deffontaines, J. P., and Osty, P. L., 1977. Des systèmes de production agricole aux systèmes agraires, Présentation d'une recherche. L’Espace Géographique, n 3, 195-199, Paris.

Deffontaines, J. P., 1991. Champ. in Histoires de géographes, Mémoires et Documents de géographie, Centre National de la Recherche Scientifique - CNRS, Paris, p 27-42.

de Bonneval, L., 1993. Systèmes agraires Systèmes de production, Vocabulaire franco-anglais. Institut National de la Recherche Agronomique - CNRS, Paris.

Dufumier, M., 1995. Understand complexity: classification of farm holdings for diagnostic analysis of agrarian situations. The Rural Extension Bulletin 7, p. 17-23.

Dufumier, M., 2006. Diversité des exploitations agricoles et pluriactivité des agriculteurs dans le Tiers Monde. Cahiers Agricultures vol. 15, $\mathrm{n}^{\circ}$ 6, November-December 2006, pp. 584-588

Dufumier, M., 2007. Agriculture Comparée et développement Agricole, Revue Tiers Monde. $n^{\circ} 191$ - juilletseptembre 2007, pp. 1-16.

Ellis, F., 2000. Rural livelihoods and diversity in developing. Oxford University Press, New York. 
Fairhead J., Leach M., 1996. Misreading the African Landscape. Society and ecology in a forest-savanna mosaic. Cambridge University Press, Cambridge

Fresco, L., 1984. Comparing anglophone and francophone approaches to Farming Systems Research and Extension. Farming Systems Support Project Networking Paper $N^{\circ} 1,36$ p.

Gastellu, J. M., 1979. Mais où sont donc ces unités économiques que nos amis cherchent tant en Afrique ?, Note de travail, Série: enquêtes et outils statistiques, vol 1, "Le choix de l'unité", Amélioration des Méthodes d'Investigation en milieu Rural Africain - AMIRA, Paris, pp. 99-122.

Gibon, A., Sibbald, A.R., Flamant, J.C., Lhoste, P., Revilla, R., Rubino, R. and Sorensen, J.T., 1999. Livestock farming systems research in Europe and its potential contribution for managing towards sustainability in livestock farming. Livestock Production Science 61, pp. 121-137.

Haggblade, S., Hazell, P., Reardon, T., 2005. The Rural Nonfarm Economy: Pathway Out of Poverty or Pathway in ? IFPRI, ODI and Imperial College London, Proceeding from the Research Workshop on the Future of small Farms, June 26-29, 2005, Withersdave Coference Centre, Wye, UK.

INRA, 1977. Pays, Paysan Paysage dans les Vosges du sud, les pratiques agricoles et la transformation de l'espace, (ouvrage collectif),Institut National de la Recherche Agronomique - INRA, , Paris.

INRA, 1986. Les collines du Népal central. Ecosystèmes, structures sociales et systèmes agraires: tome I: Paysages et sociétés dans les collines du Népal ; tome II: Milieux et activités dans un village népalais, (ouvrage collectif dirigé par J.F. Dobremez), Institut National de la Recherche Agronomique - INRA, Paris.

Johnston R. J., Gregory D., Pratt G., Watts M., 2000 (fourth Edition). The dictionary of Human Geography. Blackwell Publishers Ltd, Oxford, UK.. 
Jouve, Ph., 1988. Quelques réflexions sur la spécificité et l'identification des systèmes agraires. Les Cahiers de la Recherche Développement, n 20 décembre 1988, pp. 5-16.

Jouve, Ph., 2000: "Recherche-Développement : Evolution and Perspectives", in Colin J.-Ph and Crawford E. W. (Eds.) Research on agricultural systems: accomplishments, perspectives and issues. Huntington, NY: Nova Science Publishers, Inc., 2000, pp. 49-68.

Jouve, Ph. and Tallec, B., 1994. Une méthode d'étude des systèmes agraires en Afrique de l'Ouest par l'analyse de la diversité et de la dynamique des agrosystèmes villageois. Presentation at Symposium international sur recherche-système en agriculture et développement rural, Novembre, 1994, Montpellier, France.

Khon Kaen University, 1987. Rapid Rural Appraisal. Proceedings of the 1985 International Conference, Rural Systems Research and Farming Systems Research Projects, Khon Kaen University, Thailand.

Kroll, J. C., 1992. Les politiques publiques dans le développement de l'agriculture française et européenne. Habilitation à Diriger les Recherches dissertation, Université de Paris X Nanterre, Nanterre.

Larrère, G. R., 1974. Considérations générales - et quasiment théoriques - sur les systèmes agraires, point de vue qui en dérive quant à l'articulation des recherches des biologistes et des économistes dans l'ATP environnement (Région des Dômes). Note, October 1974 (mimeo).

Levy, J. and Lussault, M., 2003. Dictionnaire de la Géographie et de l'espace des sociétés. Belin, Paris.

Marchal J. Y., 2000. “A Geographer's Viewpoint”, in Colin J.-Ph and Crawford E. W. (Eds.), 2000. Research on agricultural systems: accomplishments, perspectives and issues. Huntington, NY: Nova Science Publishers, Inc., 2000, pp. 111- 125.

Mayaud, J. L., 1999. La petite exploitation rurale triomphante, France XIXè siècle. 1999, Belin, Paris. 
Mazoyer, M., 1987. Dynamique des Systèmes Agraires. Rapport de synthèse présenté au Comité des systèmes agraires, Ministère de la Recherche et de la Technologie, Paris.

Mazoyer, M., Roudart, L., 1997. Pourquoi une théorie des systèmes agraires? Cahiers Agricultures 1997 ; 6:5915.

Mazoyer, M., Roudart, L., 2005. A History of World Agriculture: from the neolithic age to current crisis. New York: Monthly Review Press, 480 p.

Morlon, P. (ed), 1992. Comprendre l'agriculture paysanne dans les Andes Centrales, Pérou - Bolivie. INRA éditions, Paris.

Osty, P. L., 1978. L'exploitation agricole vue comme un système. Diffusion de l'innovation et contribution au développement, Technical Information Bulletin of the Ministry of Agriculture-326, pp. 43-49.

Paul, J. L., Bory, A., Bellande, A., Garganta, E., Fabri, A., 1994. Quel système de référence pour la prise en compte de la rationalité de l'agriculteur: du système de production agricole au système d'activité. Les Cahiers de la Recherche-développement, n³9, pp. 7-19.

Peet R., Watts M. (edt), 2004. Liberation ecologies. Environment, Development, Social movements. second Edition, Routledge, London and New York

Pélissier, P., 1966. Les Paysans du Sénégal. Les civilisations agraires du Cayor à la Casamance. Imprimerie Fabrègue, Saint-Yrieix (Haute-Vienne).

Pépin-Lehalleur, M., Sautter, G., 1988. Mante (tamaulipas, Mexique): un système agraire régional ? Les Cahiers de la Recherche-Développement, $\mathrm{n}^{\circ} 20$ déc. 1988, Centre International de Recherche pour l'Agriculture et le Developpement - CIRAD, pp. 17-28. 
Pillot, D., 1987. Recherche Développement et Farming System Research, Concepts, approches et méthodes. Réseau Recherche-Développement, Ministère de la Coopération, Paris.

Reboul, C., 1977. Déterminants sociaux de la fertilité des sols. Fertilité agronomique et fertilité économique. Actes de la Recherche en Sciences Sociales, 17-18, pp. 88-112.

Renard, J., 2002. Les mutations des campagnes, paysage et structures agraires dans le monde. A. Colin, Paris.

Rindos, D., 1984. The origins of Agriculture: An Evolutionary Perspective. Academic Press, Orlando, Florida.

Sautter, G., Pélissier, P., 1964. Pour un atlas des terroirs africains: structure-type d'une étude de terroir. L’Homme, 1964, IV, 1, Paris, pp. 56-72.

de Schlippé, P., 1956. Schfting cultivation in Africa, The zande System of agriculture. Routledge \& Kegan Paul, London.

Scott J.C., Bhatt N. (eds), 2001. Agrarian studies: Synthetic work at the cutting edge. Yale University Press, Newhaven and London (320 p).

Sébillotte, M., 1976. Jachère, système de culture, système de production. Institut National Agronomique Paris Grignon, 1976.

Sébillotte, M. (ed), 1996. Recherches-système en agriculture et développement rural. Actes du Symposium International, 1994, Montpellier, France.

Tchayanov, A., 1924. The theory of peasant economy. ed by D. Thorner, B. Kerblay and R.E.F. Smith, The American Economic Association, Homewood, Illinois, 1966

Tiffen, M., Mortimore, M. et Gichuki, F., 1994. More people, less erosion, environmental recovery in Kenya. Overseas Development Institute, London, UK, John Wiley and Sons Editor, Chichester) 
Verdeaux, F., 1997. Quand la campagne était une 'forêt vierge'...L'invention de la ruralité en Côte d'Ivoire 1911-199..., in Gastellu, J.M. and J. Y. Marchal. La ruralité dans les pays du Sud à la fin du XXè siècle. Editions de l'ORSTOM, Paris, 1997,pp. 79-97

Zandstra, H.G., 1982. Institutional requirements for cropping systems research. Cropping Systems Research in Asia, IRRI, Los Banos. 